\title{
Bank Regulatory Reform In The United States: The Case Of Goldman And The Volcker Rule
}

Elizabeth Holowecky, Cleveland State University, USA Ashley Murry, Cleveland State University, USA Violeta Staneva, Cleveland State University, USA Jayne Fuglister, Cleveland State University, USA

\begin{abstract}
This case is an ethics case. The focus is on corporate governance in a major Wall Street bank, Goldman Sachs. The case discusses what Congress has done in the past and what it may do in the future to prevent breaches in ethics relating to proprietary trading. In response to the current financial crisis, Congress has proposed many changes for the banking industry and the proposals have gained momentum because of the SEC's accusation of fraud at Goldman Sachs. One piece of proposed legislation, endorsed by President Barack Obama and former chairman of the Federal Reserve, Paul Volcker, is based on the Volcker Rule. This rule would return the banking industry to the decades of the Glass-Steagall provisions of the Banking Act of 1933. The Volcker Rule would reinstitute the separation of commercial and investment banking.
\end{abstract}

Keywords: Ethics Case; Corporate Governance; Financial Crisis

\section{INTRODUCTION}

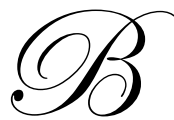

anks and other financial institutions play an integral role in the functioning of the economy. They serve as financial intermediaries and without them funds from those who save would not be available to those with the ability to utilize funds for various investment opportunities. Financial intermediaries include depository institutions, contractual savings institutions and investment intermediaries. All financial intermediaries play a role in the economy, but the principal intermediary is the depository institution which includes commercial banks, savings and loan associations, mutual savings banks and credit unions. These institutions help ensure that the economy and financial markets run smoothly - supplying credit in the form of business, education, car and home loans and checking and savings account services (Mishkin, 2001, p. 211). The sources of funds for these financial intermediaries come in the form of deposits while the primary uses of those deposits vary according to the type of depository institution. Commercial banks have the widest range of uses for their deposits and are the largest type of depository institution in the United States (Mishkin, 2001, p. 38).

The purchase and sale of derivatives and other securities by commercial banks has proven to be an area of controversy due to its speculative and inherently risky nature. These activities are viewed by many to be suitable only for investment banks, not for commercial banks.

\section{THE GREAT DEPRESSION}

Prior to the Great Depression, commercial banks engaged in activities similar to investment banks and these activities are cited as a major cause of the financial panic from 1929-1933. In efforts to increase profits commercial banks engaged in investment bank-like activities such as issuing, selling, and underwriting corporate and government securities and purchasing securities for their own accounts (so-called proprietary or "prop" trading), in addition to other speculative activities. "Many banks, especially national banks, not only invested heavily in 
speculative securities but entered the business of investment banking in the traditional sense of the term by buying original issues for public resale" (Benston, 1990, p. 11). This financial crisis not only crippled the U.S. banking system - more than 11,000 banks either failed or had to merge - but also caused many Americans to lose savings that were held at commercial banking institutions. The actions of these commercial banks contributed to a loss of confidence in the U.S. banking system. As a result, the Banking Act of 1933 was passed by Congress. This act, in addition to establishing the Federal Deposit Insurance Corporation, which provides insurance on bank deposits, established strict regulations on the commingling of commercial and investment banking activities.

\section{GLASS-STEAGALL}

"The 'Glass-Steagall' Act has come to mean only those sections of the Banking Act of 1933 that refer to banks' securities operations - sections 16, 20, 21, 32" (Benston, 1990, p.7). George J. Benston cites a brief filed by the First National City Bank: "The Glass-Steagall Act was enacted to remedy the speculative abuses that infected commercial banking prior to the collapse of the stock market and financial panic of 1929-1933" (1990, p. 11). It was a law meant to separate commercial and investment banking activities. The provisions of this act "prohibited commercial banks from underwriting or dealing in corporate securities [...] and limited banks to the purchase of debt securities approved by the bank regulatory agencies" (Mishkin, 2001, p. 250). The act also required commercial banks to discontinue their investment banking operations. Not only did this legislation restrict the activities of the commercial banks, it also prohibited investment banks from acting in a commercial banking capacity.

\section{Provisions of Glass-Steagall}

Sections 16 and 21 of Glass-Steagall-in reference to the direct operations of commercial banking institutions, prohibited member banks of the Federal Reserve from purchasing securities for their own account. These sections also prevented deposit-taking institutions from engaging in "issuing, underwriting, selling, or distributing, at wholesale or retail, or through syndicate participation, stock, bonds, debentures, notes or other securities" (Benston, 1990, p. 7). There were exceptions to those restrictions: "U.S government obligations, obligations issued by government agencies, college and university bonds, and the general obligations of states and political subdivisions" (Benston, 1990, p. 7). On the other hand, section 16 did permit commercial banks to purchase and sell securities directly on the order of and for the account of their customers. The banks were also permitted to act as advisers and agents in the private placement of commercial paper (Benston, 1990, p.7).

The remaining sections, 20 and 32, reference commercial banks' affiliations. Benston defines an "affiliation" to exist when "a common set of stockholders controls 50 percent or more of both the commercial bank and investment company" (Benston, 1990, p. 8). Under section 20, commercial banks were prohibited from "affiliating with a company engaged principally in the issue, flotation, underwriting, public sale or distribution at wholesale or retail or through syndicate participation of stocks, bonds, debentures, notes or other securities" (Benston, 1990, p. 8). "Principally engaged" is defined by the Federal Reserve to mean "activities contributing more than from 5 to 10 percent of the affiliate's total revenue" (Benston, 1990, p. 9). Future rulings from the Federal Reserve clarified the restrictions on commercial banks' affiliations, determining that commercial banks could acquire subsidiaries that provide both brokerage service and investment advice to institutional customers. Affiliates were also permitted to offer retail discount brokerage services due to the fact that these activities did not involve an underwriting of securities. Section 32 applied to senior management executives of member banks. Member banks were prohibited, under this section, "from having interlocking directorships or close officer or employee relationships with a firm that is principally engaged in securities underwriting and distribution" (Benston, 1990, p.7-8).

\section{Rationale}

There are many reasons why Glass-Steagall was incorporated into the Banking Act of 1933 and many arguments for its continuance. Glass-Steagall was thought to be the solution to the commercial and investment banking problems that were presumed to be the cause of financial panic. The attorney of First National City Bank, during a brief, cited "three well-defined evils [...] found to flow from the combination of investment and 
commercial banking" (Benston, 1990, p. 11): (1) banks chose to invest their assets in securities which resulted in risk to commercial and savings deposits; (2) unsound loans were made as a means to increase the price of securities or the financial positions of the companies in which commercial banks had invested their own assets; (3) a commercial banks' financial interest in the ownership, price, or distribution of securities encouraged bank officials to urge customers to invest in securities that it was under pressure to sell due to its own stake in the transaction (Benston, 1990, p. 11). In addition, former chairman of the Federal Reserve Paul Volcker, reasons that as the commercial banks became more involved in securities, the public lost its confidence in the banking system: "Confusion by the public as to whether they were dealing with a bank or its securities affiliate and loss of confidence in the banking system were also cited as adverse consequences of the securities affiliate system" (Benston, 1990, p. 12).

The integration of commercial and investment banking activities resulted or had the potential to result in a number of unwanted circumstances for the public, the U.S. government, and the entire banking system. By engaging in underwriting and holding corporate securities, the risk of loss to depositors and the federal government was substantial. The conflicting interests of the commercial banks involved in securities activities had the potential to result in harm to customers. Commercial banks also introduced unwanted competition to securities brokers and underwriters. The federal deposit insurance afforded member banks cheap deposits; thereby, providing an unfair competitive advantage to commercial banks engaging in securities activities. The investment banking activities of commercial banks brought with them the increased likelihood that the FDIC would be called upon to rescue failing member banks (Benston, 1990, p. 13). The prevention of the aforementioned consequences, however, did not protect the act from encountering opposition.

\section{The Repeal}

Daniel Tarullo describes the decades following the passing of the Banking Act of 1933 as "quiet and predictably if unspectacularly profitable" $(2008$, p. 34$)$ for the banking industry. Despite the rationale behind a separation of commercial and investment banking and the seeming success of the Glass-Steagall provisions there was much opposition to this legislation. The principle argument against Glass-Steagall was that within such a rapidly changing financial environment, the restrictions of Glass-Steagall prevented commercial banks from remaining competitive (Tarullo, 2008, p. 34).

The affiliation restrictions "barred [commercial banks] from realizing what many believed to be a potentially important source of earnings diversification" (Tarullo, 2008, p. 34). As a result, commercial banks requested a relaxation of the prohibitions on their ability to explore new markets and lines of business. Concerned with the possibility that the banking system would be weakened if banks were constrained in their response to new competition, regulatory agencies began to relax or remove many of the regulatory devices that had insulated the commercial banks during the decades following the Glass-Steagall legislation (Tarullo, 2008, p. 35).

In 1987, the Federal Reserve used a loophole in section 20 of Glass-Steagall to allow bank holding companies to underwrite classes of securities previously prohibited. As described previously, section 20 only prohibited commercial banks from having affiliates that were "principally engaged" in securities activities. Thus, commercial banks began to permit their affiliates to engage in securities activities as long as the revenue from these activities did not exceed 10 percent of the affiliate's total revenue. This 10 percent threshold was later relaxed to 25 percent. Soon thereafter, banks began to enter the underwriting business and brokerage firms entered the traditional banking business (Mishkin, 2001, p. 259). "The pursuit of profits and financial innovation stimulated both banks and other financial institutions to bypass the intent of the Glass-Steagall Act and encroach on each other's traditional territory" (Mishkin, 2001, p. 259). In 1999, the Glass-Steagall Act was repealed.

\section{7-2009 FINANCIAL CRISIS}

Ten years after the repeal of Glass-Steagall, the world is scrambling to recover from what has been deemed the worst financial crisis since the Great Depression. There are many factors that contributed to the current financial crisis. These factors include the development of the Community Reinvestment Act, the creation and securitization of sub prime mortgages, and the buying and selling of these securities by banks. 
As a means to meet the requirements of the Community Reinvestment Act — an act implemented to increase the ability of all Americans to become homeowners - sub prime mortgages were created. Most of these sub prime mortgages were issued with variable interest rate terms that allowed borrowers to make monthly payments only towards interest, with no money being allocated to the principal amount of the loan. These interest-only payments would be in place for the first few years of the mortgage; thereafter, the monthly payment would increase substantially to include payments toward principal.

As interest rates rose, so did the monthly payments on the sub prime mortgages. At the same time, for many sub prime borrowers, the interest-only payments were converting to interest plus principal payments. The combination of those factors decreased the ability of borrowers to meet their mortgage obligations - they defaulted on loans and foreclosures skyrocketed.

The aforementioned factors combined to cause significant increases in unemployment rates, decreases in the amounts of credit banks are willing to issue, and numerous bank failures. The housing market has slumped considerably due to declines in the value of homes and the number of home foreclosures has increased astronomically. During recent months, the FDIC has forced several banks to close - continuing the trend of 2009 which saw 140 bank failures (Gordon, 2010, Para. 1). Approximately 15 percent of mortgages were either delinquent or facing bank seizure, during the final quarter of 2009 - the highest rate since 1972 (Merle, 2010 , Para. 8). The value of the average home in the United States decreased by approximately 4.1 percent between 2008 and 2009 (Levy, 2010, Para. 10).

\section{ROLE OF COMMERCIAL BANKS}

It is difficult to quantify the extent to which the financial crisis is the result of the speculative activities of commercial banks. It is, however, somewhat easier to determine the actions of the commercial banks that contributed to the current financial crisis. The commercial banks' movement from risky business strategies to extreme risk aversion played an integral role in the current financial crisis. According to one economist, "commercial banks [have] made the large mistakes by having no conscience of the risk they were taking and then immediately becoming extraordinarily risk averse without taking any responsibility for the crucial role they play for the operations of the market" (Wyplosz, 2008).

As previously discussed, banks are intermediaries and they function to channel funds from lender-savers to borrower-spenders. It is crucial to keep these channels open in order for the economy to function effectively. Duca, DiMartino, and Renier (2009), of the Dallas Federal Reserve liken this critical flow to that of a cardiovascular system:

An apt metaphor is the cardiovascular system, which sustains the human body. In like fashion, financial flows provide critical sustenance to the economy, channeling funds to borrowers and payments back to lenders. In both biology and finance, blockages are unhealthy. Indeed, the financial system's seizing up in the last quarter of 2008 triggered the sharpest decline in domestic economic growth since the credit crunch of 1980. (Duca et al, Para. 3)

The commercial banks play a critical role in the economy and undoubtedly had a role in the subprime mortgage process.

In the sub prime mortgage securitization process, commercial banks played the role of buying and selling securities that were backed by sub prime mortgages. In the pursuit for profits, these deposit-taking institutions engaged in risky securities dealings without much regard for the potential losses that could and, eventually, did occur.

Many of [the world's largest banks] had bought huge amounts of what has come to be called toxic assets-based on mortgages and sub primes [...] without really asking any questions and without apparently understanding exactly what they were doing. [...] They were very brave and not very cautious when [trading] (Wyplosz, 2008).

Rising interest rates caused an increase in the rate of sub prime mortgage foreclosures. This had an inevitable effect on the value of the sub prime mortgage backed securities that were held on the books of commercial banks. 
The foreclosure crisis began to noticeably affect the banking industry in the summer of 2007, when a number of European investment funds stopped their redemptions due to their inability to value portions of their portfolios that contained sub prime mortgage backed securities (Duca et al., 2009, Para. 9). This uncertainty in asset values triggered a desire in banks to increase their liquidity. "Institutions hung on to extra liquidity to meet their own funding needs. And they feared lending to institutions whose default risk had risen because of exposure to sub prime mortgages and other suddenly suspect assets" (Duca et al., 2009, Para. 9).

The freezing of the inter-bank lending market—which arose as a means to provide banks with unfunded investment opportunities the ability to borrow from other banks that carried excess funds, at low interest ratesprevented banks from relying on this market as a means to meet their funding necessities. The restrictions on the availability of these interbank funds caused banks to reexamine their lending policies.

As banks realized the toxicity of the securities that were being purchased and sold within the industry, they became extremely risk averse - credit lending policies were tightened, sub prime and commercial lending criteria strengthened, and inter-bank lending all but stopped. This blockage, according to Duca et al. (2009), resulted in the "significant choking off of economic activity" (Para. 5). The availability of credit is vital to the efficient functioning of the economy. The sudden movement of commercial banking institutions to risk-averse business models has helped to push the country from a financial crisis into an economic crisis.

\section{THE VOLCKER RULE}

In response to the current economic crisis, there have been many attempts by Congress to pass regulation that would prevent the country and the world from experiencing another debacle of this magnitude. The pace of financial regulation reform has been slow and there has not been much passed in the way of legislation. On January 21, 2010, President Barack Obama took a step in the direction of banking reform by announcing his support of The Volcker Rule.

The Volcker Rule - named for former Federal Reserve chairman and one of the largest proponents of banking reform, Paul Volcker-is the basis for proposed legislation meant to impose strict regulations on financial institutions with liabilities backed by the Federal Deposit and Insurance Corporation. The Rule calls for a separation of commercial and investment banking activities. The Volcker Rule would no longer allow banks to "own, invest, or sponsor hedge funds, private equity funds, or proprietary trading operations for their own profit, unrelated to serving their customers" (White House Press Release, 2010).

The proposals emphasize the need to eliminate the ability of those banks with access to the FDIC "safety net" and Federal Reserve to engage in speculative activities. U.S. Treasury Deputy Secretary Neal Wolin, who testified alongside Paul Volcker to the Senate Banking Committee, said "banks that do proprietary trading enjoy a cheaper cost of capital because of taxpayer backing of the deposit-funded sides of their business models, which is unfair" (Drawbaugh \& Younglai, 2010, para. 20). When declaring his support for The Volcker Rule, President Obama stated the purpose of the Federal Deposit Insurance:

Our government provides deposit insurance and other safeguards and guarantees to firms that operate banks. We do so because a stable and reliable banking system promotes sustained growth, and because we learned how dangerous the failure of that system can be during the Great Depression. (White House Press Release, 2010).

Because many of the failing financial institutions were protected by the FDIC, the U.S. taxpayers have been forced to provide more than 200 billion dollars of bailout money in an effort to salvage the U.S. financial system. Many of those institutions that received a bailout from taxpayers chose to engage in overly risky speculative activities. The Volcker Rule is asking those institutions such as JP Morgan, Goldman Sachs, and Bank of America to choose which activities they want to conduct - those of investment banks or those of deposit-taking institutions. Those institutions that remain in the business of owning, investing and operating hedge funds, private mutual funds, and proprietary trading for their own profit will do so without the banking license (Volcker, 2010). According to Volcker, in reference to those institutions that choose to forgo their bank status, "if they got in trouble, the theory is they will not be rescued, but they will have an orderly demise where I think of as euthanasia rather than life support and that's a big difference" (Volcker, 2010). 
Another issue addressed by The Volcker Rule, is the inherent conflict of interests that arises when a bank engages in both investment and commercial banking activities. A manager of an institution that is in the business of accepting deposits from consumers while also in the business of making speculative investments for its own profit, is unlikely to maintain his or her objectivity when managing the money of its depositors. Volcker describes this conflict as a difference in thinking between the proprietary trader and the commercial banker:

[...]basic commercial banking serving the public, serving your customers, providing solid services at reasonable costs and safely is a different mentality than the typical proprietary trader, typical hedge fund guy. I'm not saying it's wrong. It's just different. [...]I also think it is apparent that a lot of this trading activity raises enormous conflicts of interest within these institutions which are themselves, at the very least, the most mildest comment I can make, are very difficult to manage. (Volcker, 2010)

\section{CRITICS OF THE VOLCKER RULE}

One argument against the separation of commercial and investment banking activities is that the commingling of these activities did not cause the current financial crisis, albeit they did play an integral role. Paul Volcker has admitted that such restrictions would not have prevented the problems at AIG and Lehman Brothers, but has also warned that without limits to proprietary trading, the country will experience another financial crisis (Drawbaugh \& Younglai, 2010, para. 4). Regulation addressing not only the root cause of the crisis, but also the factors that contributed to its magnitude is necessary.

Douglas Elliot, a previous president and principal researcher for the Center on Federal Financial Institutions and an investment banker for two decades mostly at JP Morgan, criticizes the Volcker Rule because "the plan to limit proprietary investments is problematic for a number of reasons. It is so vague that we may find that the eventual details are downright harmful to the economy." He is quoted in a CNNMoney article as saying "The thing is, loans have become instruments that are pretty fairly traded. You can't tell me the characteristics of a loan that makes it different from a security."

Peter Wallison of the Wall Street Journal is another critic of the Volcker plan. He states that "Banks have been committing themselves increasingly to financing real estate. The reason for this is simple. Because they cannot underwrite or deal in securities, they have been losing out to securities firms in financing public companies - that is, most of American business other than small business. It is less expensive for a company to issue notes, bonds or commercial paper in the securities markets than to borrow from a bank."

\section{SUPPORT FOR VOLCKER RULE}

Volcker addresses both Elliot and Wallison's arguments by asserting that it is not about the amount risk, but about which risk is essential to the functioning of the economy and which is not. According to Volcker, it is "hedge funds, private equity funds, and trading activities unrelated to customer needs and continuing banking relationships (that) should stand on their own, without the subsidies implied by public support for depository institutions."

While The Volcker Rule is bound to face much opposition, just as the Glass-Steagall Act faced decades ago, the proposal has also received much support from not only the American public, but from previous secretaries of treasury. A poll conducted in February of the current year by the Chartered Financial Analyst Institute showed that 68 percent of the 1,494 participants are in support of the proposed separation of commercial and investment banking activities (Weidner, 2010, para. 3). As recent as February 22, 2010, five previous secretaries of Treasury for both Republican and Democratic parties, have written letters in support of The Volcker Rule-W. Michael Blumenthal, Nicholas Brady, Paul O'Neill, George Schultz, and John Snow (O'Neill et al, 2010, para 1). A former opponent of the Volcker Rule, U.S. Senate Banking Committee Chairman Chris Dodd, has stated his strong support for the restriction of commercial banks from engaging in proprietary trading, owning hedge funds, or private equity arms (Boles, 2010, para. 1). Also the Merkley-Levin Amendment to the Senate bill 'creates a wall between hedge fund investments and deposits" (Newman, 2010). There is political support for a bill based on the Volcker Rule. 
The repeal of Glass-Steagall in 1999 introduced

... a system in which hedge fund s or private equity firms inside banks can place huge, risky bets that are subsidized by taxpayers [...] a system in which shareholders make money on these operations if the bank wins but taxpayers foot the bill if the bank loses. (White House Press Release, 2010)

A good number of institutions welcomed taxpayer deposits while also welcoming extremely risky business strategies and, due to a lack of regulation, the U.S. government was burdened to save them. Economist, Charles Wyplosz accurately describes tendencies of financial operators:

Financial operators love to take risks but they are not very great when the losses come. And when they make profits they are quick to pocket them; when they make losses they are quick to get public support to cover them and that is not right. (Wyplosz, 2008)

In the wake of this financial crisis, financial regulators and operators must remember the role of the commercial banks in our economy. These financial intermediaries have the role of channeling money from those who save to those who spend. According to Henry Kaufman, "financial institutions are not just the guardians of credit, but in a broader sense they are also the mechanisms that can either strengthen or weaken a market-based society" (2009, p. 44). Commercial banking was meant to be a heavily regulated industry-its liabilities are protected by the Federal Deposit Insurance; it has access to the Federal Reserve. The commercial bank should be able to be regarded as a safe haven for taxpayers' deposits.

The commercial bank should be seen as having a fiduciary responsibility to the public. "Substantial risk taking and entrepreneurial zeal belong properly in the world of commerce and trade, where large equity capital tends to reside, and not in financial institutions that are heavily endowed with other people's money" (Kaufman, 2009, p. 44). Those consumers with the desire to engage in investment activities can, and will, do so via the investment banking institutions. On the other hand, those risk-averse consumers should have the ability to depend on commercial banks to refrain from using customer deposits to engage in undesired risky activities.

The Volcker Rule, as did the Glass-Steagall provisions of The Banking Act of 1933, provides protection from the likelihood that the government and taxpayers will be held financially accountable for investment banking activities in the event of future financial crises. The Volcker Rule returns commercial banks to their core business. It is undeniable that financial institutions play a vital public role; therefore, this and other proposed banking regulation should be considered with little regard to inequities in the market today or the inflexibility of U.S. financial institutions to compete with growing financial markets in the United States and overseas (Kaufman, 2009, p. 45). After all, regulators considered these factors when the decision was made to repeal Glass-Steagall. Now, the United States and the world are struggling to bounce back from the biggest financial and economic crisis since The Great Depression.

\section{THE CASE OF GOLDMAN}

\section{The Abacus Deal}

In April, 2007 the investment bank, Goldman Sachs and hedge firm, Paulson \& Co., brokered a deal in which Paulson selected bonds and Goldman packaged them into synthetic collateral debt obligations (CDOs), called Abacus 2007-AC1. Paulson selected the securities and then, with Goldman's knowledge, bet against them. Thinking that the portfolio of the CDOs was selected by a third independent party (ACA Management LLC), sophisticated clients bought the securities. Moody's Investors Service rated the CDO deal triple A. However, by May, 2009, the deal turned out to be worthless.

Mr. Chen, the former Moody's analyst, called the Abacus deal a "rating arbitrage" trade. In other words, despite the triple A rating, eventually the true, lower value of the bonds would be revealed. 
... According to the SEC, investors in Abacus lost more than $\$ 1$ billion. The Paulson firm profited by about $\$ 1$ billion." (Lucchetti and Ng, 2010).

\section{Goldman Becomes A BHC}

In 2008 after Lehman Brothers' failure and AIG's collapse, Goldman Sachs requested to change its status to a bank holding company. The transformation imposed higher capital requirements, additional disclosure regulations, and stricter government oversight. However, the shift was a strategic move for Goldman to organize commercial bank subsidiaries and to obtain access to the FDIC "safety net" and Federal lending. Part of the trade-off was the $\$ 10$ billion received under TARP. By becoming a bank holding company...

it was a blunt acknowledgment that their [Goldman] model of finance and investing had become too risky and that they needed the cushion of bank deposits that had kept big commercial banks like Bank of America and JPMorgan Chase relatively safe amid the recent turmoil. (Corking and Baja, 2008)

\section{SEC Allegations Against Goldman}

Current SEC allegations that Goldman fraudulently provided inadequate disclosure to clients in the Abacus deal reveal that Goldman managed to enjoy the best of all worlds: Federal Reserve lending under TARP after they became a BHC, high-risk proprietary trading before they became a BHC, and trading in an environment with weak regulation before they became a BHC.

\section{SEC Allegations Against Moody's}

The SEC is investigating whether Moody's issued reckless descriptions of its credit-rating policies. On March 18, 2010 the SEC announced that the rating process may be the cause of an SEC lawsuit.

\section{Audit Of The Fed And Goldman's Tarp Funding}

In May, 2010 the Senate announced a GAO audit of the Federal Reserve Board's process in issuing TARP funds to Goldman. (Lightman, 2010)

\section{Required:}

1. What is the role of commercial banks in the U.S. economy?

2. Describe the operations of investment banks, as opposed to commercial banks.

3. What was the Glass-Steagall Act and why was it passed? Why was it repealed?

4. Do you think the Volcker Rule should become the basis of new bank regulations?

5. Do you think that Goldman defrauded its clients? If so, how?

6. Would a Congressional Regulation based on the Volcker Rule have stopped Goldman from its questionable business practices?

7. Would restricting Goldman's proprietary trading operations have limited systematic risk?

8. What action should Goldman take if the Volcker Rule is enforced?

9. What regulatory loopholes has the case of Goldman exposed?

10. What are the challenges of enforcing the Volcker Rule?

11. How are ratings agencies such as Moody's involved in the financial crisis?

12. How does the categorical imperative apply to the Goldman and Moody cases?

\section{CONCLUSION}

This ethics case demonstrates that behavior is fashioned by corporate culture, not by financial regulation. If the 'tone at the top' is to exploit clients for short term gains, then managers will find ways to circumvent financial regulations. New regulations will probably give rise to new ways to circumvent them. It also demonstrates that clients, especially institutional, need to do their own due diligence so they are not easy prey. 


\section{AUTHOR INFORMATION}

Elizabeth Holowecky is a recent graduate from Cleveland State University where she earned her MBA with a concentration in Accounting. She completed her undergraduate degree at John Carroll University where she majored in Accountancy. Her professional experience is in public accounting.

Ashley Murry earned her Bachelor of Science in accounting from Case Western Reserve University Weatherhead School of Management and her Master of Accountancy from Nance School of Business at Cleveland State University. She is currently employed at the NASA Glenn Research Center. She is also studying to sit for the Uniform CPA exam and has plans to become a Certified Fraud Examiner shortly thereafter.

Violeta Staneva earned her bachelor and Master's degree from the University of Economics - Varna, Bulgaria in International Economic Relations and International Business, respectively. After immigrating to the USA, she earned her Master of Accountancy from Nance School of Business at Cleveland State University.

Jayne Fuglister is a Professor of Accounting, Nance School of Business, at Cleveland State University.

\section{REFERENCES}

1. Benston, G. (1990). The separation of commercial and investment banking: The Glass-Steagall Act revisited and reconsidered. New York, NY: Oxford UP.

2. Boles, C. (2010). $4^{\text {th }}$ Update: US Senator Dodd: Strongly Supports 'Volcker Rule'.

3. $\quad$ NASDAQ Stock Market - Stock Quotes - Stock Exchange News - NASDAQ.com. Retrieved from :< http://www.nasdaq.com/aspx/company-newsstory.aspx?storyid=201002021805dowjonesdjonline 000512\&title=4th-update-us-senator-dodd-stronglysupports-volcker-rule>.

4. Corking, A., \& Baja, V. (2008). Shift for Goldman and Morgan Marks the End of an Era. The New York Times. Retrieved from: http://www.nytimes.com/2008/09/22/business/22bank.html? r=1.

5. Date, R. (2010). Through the Looking Glass (Steagall): Banks, Broker Dealers and the Volcker Rule. Cambridge Winter Center for Financial Institutional Policy.

6. Drawbaugh, K., \& Youngman, R. (2010). Volcker urges curbs on big banks' risky trades $\mid$ Reuters. Business \& Financial News, Breaking US \& International News | Reuters.com. Retrieved from: $<$ http://www.reuters.com/article/idUSTRE6112T320100202>.

7. Duca, J., Dilation, D., \& Render, J. (2009). Fed confronts financial crisis by expanding its role as lender of last resort. Federal Reserve Bank of Dallas. Retrieved from: <http://dallasfed.org/research/eclett/2009/el0902.html>.

8. Gordon, M. (2010). Banks in Calif., Ill., Fla., and Texas are shut down. ABCNews.com - Breaking news, politics, online news, world news, feature stories, celebrity interviews and more. Retrieved from: $\langle$ http://abcnews.go.com/Business/wireStory?id=9892595 >.

9. Hall, K.G. (2010). Finance bills fail to address ratings agencies. McClatchy Newspapers, May 9, 2010.

10. Kaufman, H. (2009). The road to financial reformation: Warnings, consequences, reforms. Hoboken, NJ: John Wiley \& Sons.

11. Levy, D. (2010). U.S. foreclosure filings top 300,000 for $11^{\text {th }}$ month (Update1). Business Week - Business News, Stock Market \& Financial Advice. Retrieved from: <http://www.businessweek.com/news/2010-0211/u-s-foreclosure-filings-surpass-300-000-for-11th-month-in-row.html $>$.

12. Lightman, D. (2010). Fed's bailout record to get GAO scrutiny: Senate votes 96-0 to follow the money. McClatchy Newspapers, The Cleveland Plain Dealer, C-2, Business. May 12, 2010.

13. Lucchetti, A. and Serena Ng (2010). Abacus Deal: As Bad as They Come. Wall Street Journal. Retrieved from: http://online.wsj.com/article/SB10001424052748703757504575194521257607284.html

14. Merle, R. (2010). Mortgage delinquency rate slows in fourth quarter. Washingtonpost.com - nation, world,technology and Washington area news and headlines. Retrieved from:

$<$ http://www.washingtonpost.com/wpdyn/content/article/2010/02/19/AR2010021902471.html?hpid=topnews>. 
15. Mishkin, F. (2001). The economics of money, banking, and financial markets. The Addison-Wesley Series in Economics. New York, NY: Addison Wesley.

16. Newman, J. (2010) Berkley-Levin Amendment Aims to Bring Integrity Back to Marketplace. Public Citizen. Retrieved from <http://www.nasdaq.com/aspx/company-newsstory.aspx? storyid=201002021805dowjonesdjonline000512\&title=4th-update-us-senator-dodd-stronglysupports-Volker-rule>.

17. O'Neill, P., Schultz, G., Brady, N., Blumenthal, M., \& Snow, J. (2010). Congress should implement The Volcker Rule for banks. Wall Street Journal. Retrieved from: http://online.wsj.com/article/SB20001424052748703983004575074123680183534.html.

18. Tarullo, D. (2008). Banking on basel: The Future of International Financial Regulation. Washington, DC: Peterson Institute for International Economics.

19. Volcker, P. (Interviewee) \& Freeland, C. (Interviewer). Interview with Paul Volcker [Interview transcript]. Retrieved from Financial Times Web site: $<$ http://www.ft.com/cms/s/0/780d9d64-175d-11df-87f600144feab49a.html

20. Wallison, P. (2010) The President's Bank Reforms Don't Add Up. The Wall Street Journal. 25 January 2010. Retrieved from: http://online.wsj.com/article/SB10001424052748704509704575019333516533828.html

21. Weidner, D. (2010). Volcker rule dead? Not so fast. MarketWatch -Stock Market Quotes, Business News, Financial News. Retreived from: $<$ http://www.marketwatch.com/story/volcker-rule-dead-not-so-fast-2010$\underline{02-19>\text {. }}$

22. Weil, J. (2010). Goldman Slapped. Bloomberg Businessweek. April 26-May 2, 2010.

23. White House. (2010). Office of the Press Secretary. Remarks by the President on financial reform. The White House. Retrieved from: 〈http://www.whitehouse.gov/the-press-office/remarks-president-financialreform>.

24. White House. (2010). Office of the Press Secretary. Remarks by the President on financial reform. The White House. Retrieved from: 〈http://www.whitehouse.gov/the-press-office/remarks-president-financialreform>.

25. Wyplosz, C. (Interviewee) \& Vaitilingam, R. (Interviewer). (2008). Commercial banks and the financial market crisis of 2007/2008 [Interview audio file]. Retreived from VOX: Research-Based Policy Analysis and Commentary from Leading Economists website: 〈http://www.voxeu.org/index.php?q=node/1294> . 